\title{
FRASE NOMINAL ATRIBUTIF DALAM RUBRIK OPINI HARIAN RAKYAT POS
}

\author{
Selvia Heryati ${ }^{1}$, \\ Universitas Ahmad Dahlan \\ selvia1700003027@webmail.uad.ac.id \\ Sudaryanto ${ }^{2}$ \\ Universitas Ahmad Dahlan \\ sudaryanto@pbsi.uad.ac.id
}

\begin{abstract}
ABSTRAK
Penelitian ini bertujuan untuk menganalisis pola frase nominal atributif dan hubungan makna antarunsur frase nominal atributif dalam rubrik "opini' harian Rakyat Pos. Penelitian ini merupakan penelitian kualitatif deskriptif. Data pada penelitian ini yaitu kutipan yang mengandung antarunsur frase nominal atributif dalam rubrik "opini". Sumber data penelitian ini yaitu harian Rakyat Pos. Teknik pengumpulan data yang dapat digunakan dalam penelitian ini adalah metode simak atau penyimakan, teknik dasar sadap, dan teknik simak. Pada penelitian ini, metode agih digunakan untuk menganalisis pola frase nominal atributif. Teknik analisis lanjutan yang digunakan adalah teknik bagi unsur langsung (BUL). Teknik lanjutan yang digunakan adalah teknik sisip, teknik balik dan teknik parafrase. Berdasarkan hasil penelitian, diperoleh 7 pola frase nominal atributif, yaitu pola $\mathrm{N}+\mathrm{N}, \mathrm{N}+\mathrm{V}$, $\mathrm{N}+\mathrm{Bil}, \mathrm{N}+\mathrm{Ket}, \mathrm{N}+\mathrm{FD}, \mathrm{Bil}+\mathrm{N}, \mathrm{Sd}+\mathrm{N}$ dan 5 hubungan makna antarunsur frase nominal atributif, yaitu hubungan makna penerang, pembatas, penentu/ penunjuk, jumlah, dan sebutan Rakyat Pos. Pola frase nominal atributif yang paling banyak ditemukan dalam rubrik "opini” harian Rakyat Pos ialah pola $\mathrm{N}+\mathrm{N}$ dengan frekuensi 305 dari 594 data dan pola yang paling jarang ditemukan ialah pola $\mathrm{N}+\mathrm{Ket}$ dengan frekuensi 7 dari 594 data. Sedangkan hubungan makna yang paling banyak ditemukan adalah hubungan makna pembatas dengan frekuensi kemunculan 263 dari 594 data dan hubungan makna yang paling jarang ditemukan adalah hubungan makna sebutan dengan frekuensi kemunculan 24 dari 594 data.
\end{abstract}

Kata kunci : nominal atributif, opini, Rakyat Pos

\section{A. PENDAHULUAN}

Bahasa merupakan sarana komunikasi yang amat penting bagi kehidupan manusia. Melalui bahasa, manusia dapat menuangkan ide, gagasan, pikiran, maupun perasaan kepada orang lain. salah satu cara untuk menuangkan bahasa yaitu melalui karya tulis, baik sastra maupun ilmiah. Bahasa dapat dikaji dengan berbagai ilmu, seperti fonologi, semantik, morfologi, sintaksis, sosiolinguistik, psikolinguistik, pragmatik, dll. Kajian sintaksis sebagai subsistem bahasa mencakup kata dan satuan-satuan gramatikal serta hubungan di antara kata dan satuan gramatikal. Pada penelitian ini, satuan gramatikal yang dikaji adalah frase.

Persamaan distribusi dengan kategori kata, frase dapat digolongkan menjadi empat golongan, yaitu frase nominal, frase verbal, frase bilangan, frase keterangan, dan frase depan. Frase nominal merupakan frase yang memiliki distribusi yang sama dengan kata nominal. Keraf (dalam Ismail, 2016) menjelaskan frase sebagai suatu kesatuan yang terdiri dari dua 


\section{Lingua Rima: Jurnal Pendidikan Bahasa dan Sastra Indonesia \\ Vol. 10 No. 3 September 2021 \\ http://jurnal.umt.ac.id/index.php/lgrm}

kata atau lebih yang masing-masing mempertahankan makna dasar katanya, sementara gabungan itu menghasilkan suatu relasi tertentu, dan tiap kata pembentuknya tidak dapat berfungsi sebagai $\mathrm{S}$ dan $\mathrm{P}$ dalam konstruksi itu. Frase itu tidak membentuk makna baru melainkan makna sintaktik atau makna gramatikal. Hal ini berbeda dengan kata majemuk, di mana kata majemuk menghasilkan makna baru atau memiliki satu makna.

Frase endosentrik merupakan frase yang mempunyai distribusi yang sama dengan unsurnya, baik semua unsur ataupun salah satu unsurnya. Istilah atributif dapat dijumpai pada frase endosentrik yaitu pada golongan frase endosentrik atributif. Frase endosentrik atributif terdiri dari satu inti dan satu atribut. Frase endosentrik atributif ini merupakan golongan frase yang terdiri dari unsur-unsur yang tidak setara. Berdasarkan kategori kata, frase dapat digolongkan menjadi frase nominal, frase verbal, frase keterangan, frase depan, dan frase bilangan.

Pada penelitian ini, frase nominal yang akan dibahas adalah frase nominal yang memiliki distribusi endosentris atributif. Frase endosentris atributif (FNA) terdiri dari unsur pusat berupa nominal yang diikuti atau didahului atribut berupa nominal itu sendiri, verbal, keterangan, bilangan, frase depan, dan sandang. Frase nominal atributif memiliki pola yang beragam. Secara kategorial frase nominal atributif terdiri dari: kata atau frase nominal diikuti kata atau frase nominal $(\mathrm{N}+\mathrm{N})$. kata atau frase nominal diikuti kata atau verbal $(\mathrm{N}+\mathrm{V})$, kata atau frase nominal diikuti kata atau frase bilangan $(\mathrm{N}+\mathrm{Bil})$, kata atau frase nominal diikuti kata atau frase keterangan $(\mathrm{N}+\mathrm{Ket})$, kata atau frase nominal diikuti frase depan (N+FD), kata atau frase nominal didahului kata atau frase bilangan $($ Bil $+\mathrm{N})$, kata atau frase nominal didahului kata sandang $(\mathrm{Sd}+\mathrm{N})$.

Sedangkan hubungan makna antarunsur frase nominal atributif meliputi hubungan makna penerang, pembatas, penentu/ penunjuk, jumlah, dan sebutan. Hubungan makna 'penerang' dapat diketahui secara jelas melalui kemungkinan diletakkan kata yang diantara unsurnya. Pada hubungan makna 'penerang', atribut berfungsi menerangkan unsur pusat. Hubungan makna 'pembatas' dapat diketahui dengan ketidakmungkinan diletakkan kata yang, dan, atau, dan adalah diantara unsur frase yang terdiri dari $\mathrm{N}+\mathrm{N}$. Pada hubungan makna 'pembatas', atribut membatasi unsur pusatnya. Hubungan makna penentu/penunjuk ditandai dengan adanya kata ganti penunjuk sebagai atribut dan dibelakang kata ganti itu tidak dapat ditambahkan atribut lagi. Hubungan makna ‘jumlah' dapat diketahui melalui frase nominal 


\section{Lingua Rima: Jurnal Pendidikan Bahasa dan Sastra Indonesia \\ Vol. 10 No. 3 September 2021 \\ http://jurnal.umt.ac.id/index.php/lgrm}

yang didahului dengan kata atau frase bilangan. Hubungan makna sebutan merupakan hubungan makna yang atributnya menyatakan sebutan bagi unsur pusatnya.

Frase nominal banyak digunakan dalam tata bahasa Indonesia. Frase nominal atributif ini dipilih untuk diteliti karena terdapat data frase nominal atributif dalam rubrik "Opini" yang dipilih. Contohnya: frase Instruktur handal terdiri dri unsur instruktur sebagai unsur pusat (UP) yang merupakan kategori kata nominal dan unsur handal sebagai atribut (Atr) yang merupakan kategori kata verbal. Hubungan makna yang dari frase instruktur handal adalah hubungan makna penerang. Hubungan makna ini ditandai dengan kemungkinan diletakkannya kata penerang. Hubungan makna ini ditandai dengan kemungkinan diletakkannya kata yang diantara unsur instruktur dan unsur handal. Jika diparafrasekan frase instruktur handal akan menjadi frase instruktur yang handal. Jadi, pada penelitian ini peneliti memilih frase nominal yang bersifat atributif yaitu frase nominal yang terdiri dari unsur pusat dan atribut. Penelitian ini bertujuan untuk mendeskripsikan pola dan hubungan makna antarunsur frase nominal atributif dalam rubrik "opini” harian Rakyat Pos.

Penelitian sebelumnya dilakukan oleh Kinanti (2020) dengan judul Frasa Nomina Atributif dalam Bahasa Jawa Dialek Jawa Timur. Penelitian ini menghasilkan Frasa Nominal Atributif (FNA) dalam bahasa Jawa merupakan frasa yang memiliki UP (unsur pusat) berupa nomina dan frasa nominal serta atribut yang terdiri dari beberapa jenis atribut, yaitu (1) FNA dengan atribut yang berkategori nomina dan frasa nominal, (2) FNA dengan atribut yang berkategori verba, (3) FNA dengan atribut yang berkategori adjektiva atau frasa adjektival, (4) FNA dengan atribut yang berkategori adverbial atau frasa adverbial, (5) FNA dengan atribut yang berkategori demonstrativa, (6) FNA dengan atribut yang berkategori numeralia, (7) FNA dengan atribut yang berkategori preposisional, (8) FNA dengan atribut yang berkategori frasa yang berunsur pusat 'sing' dengan aksis adjektiva, verba dan preposisional.

\section{B. METODOLOGI PENELITIAN}

Penelitian ini merupakan penelitian deskriptif-kualitatif. Data pada penelitian ini yaitu kutipan yang mengandung antarunsur frase nominal atributif dalam rubrik "opini”. Sumber data penelitian ini yaitu harian Rakyat Pos. Teknik pengumpulan data yang dapat digunakan dalam penelitian ini adalah metode simak atau penyimakan. Proses peminyimakan yang dilakukan adalah dengan membaca "Opini” pada harian Rakyat Pos edisi Januari 2021. Teknik pengumpulan datanya menggunakan teknik dasar dan teknik lanjut. Teknik dasar yang digunakan adalah teknik dasar sadap, yakni menyadap penggunaan bahasa ketika membaca 


\section{Lingua Rima: Jurnal Pendidikan Bahasa dan Sastra Indonesia \\ Vol. 10 No. 3 September 2021 \\ http://jurnal.umt.ac.id/index.php/lgrm}

dalam teks yang menjadi sumber data. Kemudian teknik lanjutan yang digunakan adalah teknik simak bebas libat cakap (SBLC), karena peneliti terlibat langsung dalam menyimak bacaan dalam teks yang mengandung data penelitian serta peneliti juga berperan sebagai alat.Data yang diambil dari rubrik "opini” harian Rakyat Pos edisi Januari 2021 dianalisis menggunakan metode agih. Pada penelitian ini, metode agih digunakan untuk menganalisis pola frase nominal atributif. Teknik analisis lanjutan yang digunakan adalah teknik bagi unsur langsung (BUL). Teknik ini digunakan untuk membagi frase nominal berdasarkan unsur pusat dan atribut. Setelah itu, teknik lanjutan yang digunakan adalah teknik sisip, teknik balik dan teknik parafrase. Teknik sisip dilakukan dengan menyisipkan kata yang sesuai diantara UP dan atribut untuk menemukan hubungan makna antar unsur frase nominal atributif. Selain teknik sisip, dapat pula digunakan teknik balik untuk menentukan ketegaran posisi frase nominal atributi. Kemudian, teknik parafrase yang digunakan untuk menguji ketepatan pemberian hubungan makna antar unsur frase nominal.

\section{PEMBAHASAN}

Berdasarkan hasil penelitian, diperoleh deskripsi, yaitu 1) Pola frase nominal atributif dalam rubrik “opini' harian Rakyat Pos, 2) Hubungan makna antarunsur frase nominal atributif dalam rubrik “opini' harian Rakyat Pos. Pola frase nominal atributif yang ditemukan dalam rubrik "opini”" harian Rakyat Pos sebanyak 7 pola, yaitu 1) $\mathrm{N}+\mathrm{N}$, 2) $\mathrm{N}+\mathrm{V}$, 3) $\mathrm{N}+$ Bil, 4) $\mathrm{N}+$ Ket, 5) $\mathrm{N}+\mathrm{FD}, 6)$ Bil $+\mathrm{N}, 7) \mathrm{Sd}+\mathrm{N}$. Sedangkan hubungan makna antarunsur frase nominal atributif yang ditemukan adalah 5 hubungan makna, yaitu 1) penerang, 2) pembatas, 3) penentu atau penunjuk, 4) jumlah, dan 5) sebutan. Adapun pembahasannya sebagai berikut.

\section{Pola Frase Nominal Atributif dalam Rubrik "Opini” Harian Rakyat Pos}

Sebagaimana diketahui bahwa frase nominal memiliki pola yang beragam. Tentunya dalam rubrik "opini" harian Rakyat Pos terdapat banyak pola frase yang ditemukan. Pola frase nominal atributif yang ditemukan dalam rubrik "opini” harian Rakyat Pos sebanyak 7 pola. Pola-pola yang ditemukan sudah diselaraskan dengan teori yang digunakan dalam penelitian ini. Adapun 7 pola tersebut akan dijelaskan sebagai berikut.

\section{a. Pola Nominal diikuti Nominal $(\mathbf{N}+\mathbf{N})$}

Frase nominal atributif yang berpola $\mathrm{N}+\mathrm{N}$ dalam rubrik "opini" harian Rakyat Pos merupakan pola frasa nominal yang paling banyak ditemukan. 
Frekuensi kemunculan pola $\mathrm{N}+\mathrm{N}$ adalah 305 dari 594 data yang ditemukan pada kalimat-kalimat dalam rubrik "opini" harian Rakyat Pos. Pola $\mathrm{N}+\mathrm{N}$ ini merupakan pola frase nominal yang terdiri dari kata atau frase nominal sebagai unsur pusat (UP) diikuti kata atau frase nominal sebagai atribut (Atr). Contohnya:

(1) Memiliki jumlah isi sebanyak 238 halaman, membuat buku ini memiliki narasi singkat yang ada di cover bagian belakang. (O2/446/03/21Jan21)

(2) Seandainya kedelai dijadikan tanaman utama disamping padi dan jagung, maka bisa dipastikan akan dapat memenuhi kebutuhan kedelai masyarakat Indonesia. (O2/594/12/29Jan21)

Pada kalimat (1) frase buku ini merupakan frase nominal atributif (FNA). Unsur pusat (UP) dari FNA buku ini adalah unsur buku yang merupakan kata nominal diikuti dengan unsur ini sebagai atribut yang merupakan kata ganti penunjuk. Kata ganti penunjuk dalam penggolongan kata oleh Ramlan (2005) digolongkan dalam kata nominal. Berikut diuraikan diagram pohonnya.

Buku (UP/ N) ini (Atr/ N)

Pada kalimat (2) terdapat dua frase nominal atributif (FNA) yaitu frase tanaman utama dan frase kebutuhan kedelai masyarakat Indonesia. FNA yang memiliki pola $\mathrm{N}+\mathrm{N}$ adalah frase kebutuhan kedelai masyarakat Indonesia. Unsur pusat (UP) dari FNA kebutuhan kedelai masyarakat Indonesia adalah unsur kebutuhan kedelai yang merupakan frase nominal diikuti dengan unsur masyarakat Indonesia sebagai atribut yang juga merupakan frase nominal. Berikut diuraikan diagram pohonnya.

kebutuhan kedelai masyarakat Indonesia

kebutuhan kedelai (UP/FN) masyarakat Indonesia (Atr/ FN)

kebutuhan $(\mathrm{UP} / \mathrm{N})$ kedelai $(\mathrm{Atr} / \mathrm{N})$ masyarakat (UP/N) Indonesia $(\mathrm{A} t \mathrm{t} / \mathrm{N})$

\section{b. Pola Nominal diikuti Verbal $(\mathbf{N}+\mathbf{V})$}

Frase nominal atributif yang berpola $\mathrm{N}+\mathrm{V}$ dalam rubrik "opini" harian Rakyat Pos mempunyai frekuensi kemunculan sebanyak 118 dari 594 data yang ditemukan pada kalimat-kalimat dalam rubrik "opini” harian Rakyat Pos. Pola $\mathrm{N}+$ $\mathrm{V}$ ini merupakan pola frase nominal yang terdiri dari kata atau frase nominal sebagai unsur pusat (UP) diikuti kata atau frase verbal sebagai atribut (Atr). Contohnya: 
Lingua Rima: Jurnal Pendidikan Bahasa dan Sastra Indonesia

Vol. 10 No. 3 September 2021

http://jurnal.umt.ac.id/index.php/lgrm

(3) Yang pertama adalah mengembalikan fungsi pokok orang tua sebagai pendidik utama bagi anaknya. (O1/562/06/28Jan21)

(4) Anak lambat belajar umumnya mengalami kegagalan dalam memahami pelajaran dan konsep-konsep dasar di bidang akademik, misalnya membaca, menulis, berhitung dan bahasa. (O1/430/03/21Jan21)

Pada kalimat (3) frase pendidik utama merupakan frase nominal atributif (FNA). Unsur pusat (UP) dari FNA pendidik utama adalah unsur pendidik yang merupakan kata nominal diikuti dengan unsur utama sebagai atribut yang merupakan kata sifat. Kata sifat pada penggolongan kata oleh Ramlan (2005) digolongkan dalam kata verbal. Oleh karena itu, frase pendidik utama merupakan frase nominal atributif yang memiliki pola $\mathrm{N}+\mathrm{V}$. Berikut diuraikan diagram pohonnya.

\section{Pendidik(UP/N) Utama $($ Atr/V)}

Pada kalimat (4) frase anak lambat belajar merupakan frase nominal atributif (FNA). Unsur pusat (UP) dari FNA anak lambat belajar adalah unsur anak yang merupakan kata nominal diikuti dengan unsur lambat belajar sebagai atribut yang merupakan frase verbal. Frase lambat belajar terdiri dari unsur lambat yang merupakan kata sifat dan unsur belajar yang merupakan kata kerja sehingga frase lambat belajar merupakan frase verbal. Berikut disajikan diagram pohonnya.

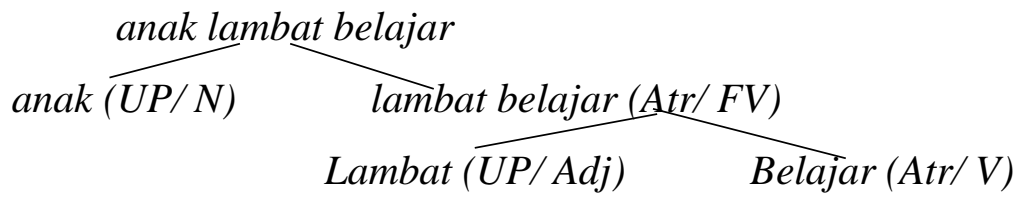

\section{c. Pola Nominal diikuti Bilangan (N + Bil)}

Frase nominal atributif yang berpola $\mathrm{N}+$ Bil dalam rubrik "opini” harian Rakyat Pos mempunyai frekuensi kemunculan sebanyak 12 dari 594 data yang ditemukan pada kalimat-kalimat dalam rubrik “opini” harian Rakyat Pos. Pola $\mathrm{N}+$ Bil ini merupakan pola frase nominal yang terdiri dari kata atau frase nominal sebagai unsur pusat (UP) diikuti kata atau frase Bilangan sebagai atribut (Atr). Contohnya:

(5) Hingga tanggal 30 Desember 2020, Lapas, Rutan dan LPKA seluruh Indonesia telah mengeluarkan narapidana dan Anak dalam program asimilasi sebanyak 69.505 orang. (O1/003/02/4Jan21) 
Lingua Rima: Jurnal Pendidikan Bahasa dan Sastra Indonesia

Vol. 10 No. 3 September 2021

http://jurnal.umt.ac.id/index.php/lgrm

(6) Firmansyah jumlah keluarga yang terdampak akibat banjir sebanyak 120.284 kartu keluarga (KK), jumlah korban yang terdampak 342.987 jiwa, dan jumlah pengungsi 63.608 orang. (O2/515/01/25Jan21)

Pada kalimat (5) terdapat dua frase nominal atributif (FNA) yakni frase seluruh Indonesia dan program asimilasi sebanyak 69.505 orang. FNA yang memiliki pola $\mathrm{N}+$ Bil adalah frase program asimilasi sebanyak 69.505 orang. Unsur pusat (UP) dari FNA program asimilasi sebanyak 69.505 orang adalah unsur program asimilasi yang merupakan frase nominal diikuti dengan unsur sebanyak 69.505 orang sebagai atribut yang merupakan frase bilangan. Berikut disajikan diagram pohonnya.

program asimilasi sebanyak 69.505 orang

program asimilasi $(U P / F N) \quad$ sebanyak 69.505 orang $($ Atr/ Fbil)

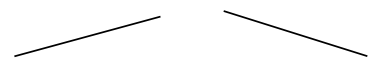

$\operatorname{program}(U P / N)$ asimilasi $($ Atr $/ N)$

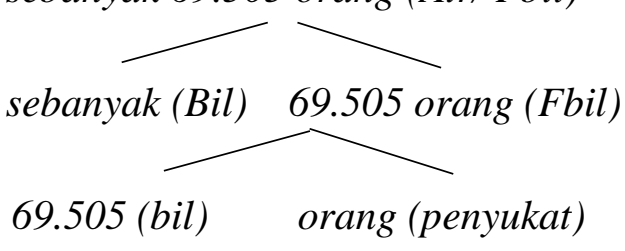

69.505 (bil) orang (penyukat)

Pada kalimat (12) frase pengungsi 63.608 orang merupakan frase nominal atributif (FNA). Unsur pusat (UP) dari FNA pengungsi 63.608 orang adalah unsur pengungsi yang merupakan kata nominal diikuti dengan unsur 63.608 orang sebagai atribut yang merupakan frase bilangan. Frase bilangan 63.608 orang terdiri dari unsur 63.608 yang merupakan kata bilangan diikuti unsur orang sebagai penyukat. Berikut disajikan diagram pohonnya.

$$
\begin{array}{r}
\text { pengungsi } 63.608 \text { orang } \\
\text { pengungsi }(U P / N) \quad 63.608 \text { orang }(\text { Atr/ Fbil) } \\
63.608(\text { bil }) \quad \text { orang (penyukat) }
\end{array}
$$

\section{d. Pola Nominal diikuti Keterangan $(N+$ Ket $)$}

Frase nominal atributif yang berpola $\mathrm{N}+$ Ket dalam rubrik "opini” harian Rakyat Pos merupakan frase nominal atributif yang paling jarang ditemukan dengan frekuensi kemunculan 7 dari 594 data yang ditemukan pada kalimat-kalimat dalam rubrik "opini” harian Rakyat Pos. Pola N + Ket ini merupakan pola frase nominal yang terdiri dari kata atau frase nominal sebagai unsur pusat (UP) diikuti kata atau frase keterangan sebagai atribut (Atr). Contohnya:

(7) Cerita adalah kekuatan yang membentuk branding sekolah kita hari ini, pun juga membangun aktualisasi sekolah di masa depan. (O1/476/05/22Jan21) 
(8) Maka dari itu, pemuda dituntut untuk berperan dengan terus berinovasi dan berprestasi di zaman yang tergerus teknologi saat ini. (O1/241/02/12Jan21)

Pada kalimat (7) frase sekolah kita hari ini merupakan frase nominal atributif (FNA) dengan pola FN + Fket yang dalam penelitian ini dikategorikan dalam pola $\mathrm{N}+$ Ket. Unsur pusat (UP) dari FNA sekolah kita hari ini adalah unsur sekolah kita yang merupakan frase nominal diikuti dengan unsur hari ini sebagai atribut yang merupakan frase keterangan. Frase nominal sekolah kita terdiri dari unsur sekolah yang merupakan kata nominal atau kata benda diikuti unsur kita yang merupakan pronominal atau kata ganti. Kata ganti dalam kelas kata Ramlan (2005) termasuk dalam golongan kata nominal. Sedangkan frase keterangan hari ini merupakan frase keterangan yang menyatakan waktu. Berikut disajikan diagram pohonnya.

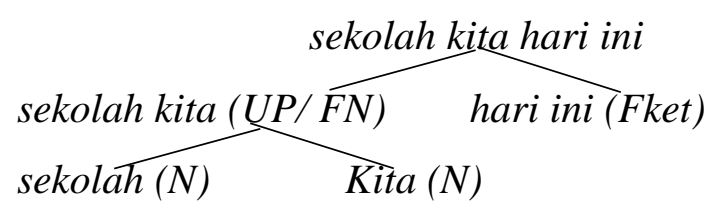

Pada kalimat (8) teknologi saat ini merupakan frase nominal atributif (FNA) dengan pola $\mathrm{N}+$ Fket yang dalam penelitian ini dikategorikan dalam pola $\mathrm{N}+$ Ket. Unsur pusat (UP) dari FNA teknologi saat ini adalah unsur teknologi yang merupakan kata nominal diikuti dengan unsur saat ini sebagai atribut yang merupakan frase keterangan. Frase keterangan saat ini merupakan frase keterangan yang menyatakan waktu. Berikut disajikan diagram pohonnya.

$$
\text { teknologi } \frac{\text { Teknologi saat ini }}{(U P / N) \quad \text { hari ini (Fket) }}
$$

\section{e. Pola Nominal diikuti Frase Depan (N + FD)}

Frase nominal atributif yang berpola N + FD dalam rubrik "opini" harian Rakyat Pos mempunyai frekuensi kemunculan sebanyak 32 dari 594 data yang ditemukan pada kalimat-kalimat dalam rubrik "opini” harian Rakyat Pos. Pola N + FD ini merupakan pola frase nominal yang terdiri dari kata atau frase nominal sebagai unsur pusat (UP) diikuti frase depan sebagai atribut (Atr). Contohnya:

(9) Peserta didik tersebut diberikan link materi untuk dipahami ditambah dengan buku penunjang dari sekolah. (O1/431/04/21Jan21) 
Lingua Rima: Jurnal Pendidikan Bahasa dan Sastra Indonesia

Vol. 10 No. 3 September 2021

http://jurnal.umt.ac.id/index.php/lgrm

(10) Berbagai upaya yang sudah digalakkan pemerintah dalam memberikan pengarahan kepada rakyatnya agar pandemi ini segera berakhir. (O1/389/02/20Jan21)

Pada kalimat (9) frase buku penunjang dari sekolah merupakan frase nominal atributif (FNA). Unsur pusat (UP) dari FNA buku penunjang dari sekolah adalah unsur buku penunjang yang merupakan frase nominal diikuti dengan unsur dari sekolah sebagai atribut yang merupakan frase depan. Frase nominal buku penunjang terdiri unsur buku yang merupakan kata nominal diikuti unsur penunjang yang juga merupakan kata nominal. Sedangkan frase dari sekolah merupakan frase eksosentrik dengan unsur dari sebagai penanda dengan kategori kelas kata depan dan unsur sekolah sebagai aksis yang merupakan kata nominal. Berikut disajikan diagram pohonnya.

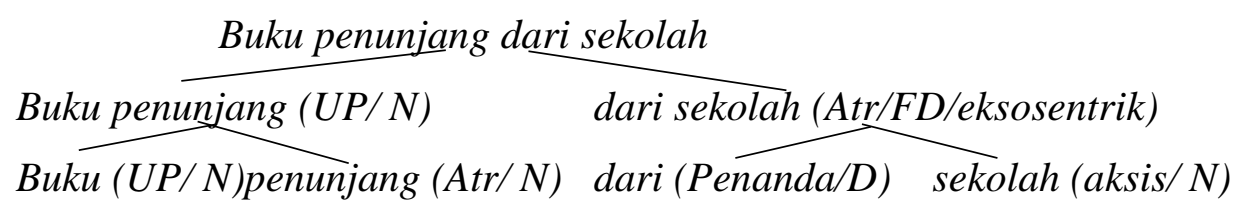

Pada kalimat (10) terdapat dua frase nominal atributif yakni frase pengarahan kepada rakyatnya dan frase pandemi ini. Frase nominal atributif (FNA) yang memiliki pola $\mathrm{N}+\mathrm{FD}$ adalah frase pengarahan kepada rakyatnya. Unsur pusat (UP) dari FNA pengarahan kepada rakyatnya adalah unsur pengarahan yang merupakan kata nominal diikuti dengan unsur kepada rakyatnya sebagai atribut yang merupakan frase depan. Frase kepada rakyatnya merupakan frase eksosentrik dengan unsur kepada sebagai penanda dengan kategori kelas kata depan dan unsur rakyatnya sebagai aksis yang merupakan kategori kata nominal. Berikut disajikan diagram pohonnya.

\section{f. Pola Nominal didahului Bilangan $(\mathrm{Bil}+\mathrm{N})$}

Frase nominal atributif yang berpola Bil $+\mathrm{N}$ dalam rubrik "opini" harian Rakyat Pos mempunyai frekuensi kemunculan sebanyak 81 dari 594 data yang ditemukan pada kalimat-kalimat dalam rubrik "opini” harian Rakyat Pos. Pola Bil + $\mathrm{N}$ ini merupakan pola frase nominal yang terdiri dari kata atau frase nominal sebagai unsur pusat (UP) didahului kata atau frase Bilangan sebagai atribut (Atr). Contoh: 
Lingua Rima: Jurnal Pendidikan Bahasa dan Sastra Indonesia

Vol. 10 No. 3 September 2021

http://jurnal.umt.ac.id/index.php/lgrm

(11) Kini, jenazah itu dikumpulkan dalam lima kantong jenazah. $(\mathrm{O} 2 / 280 / 18 / 12 \mathrm{Jan} 21)$

(12) Produksi padi tahun 2018 mencapai 83,04 juta ton, sedangkan konsumsinya hanya sebesar 30,4 juta ton beras. . (O2/592/08/29Jan21)

Pada kalimat (11) terdapat dua frase nominal atributif (FNA) yaitu frase jenazah itu dan lima kantong jenazah. FNA yang memiliki pola Bil $+\mathrm{N}$ adalah frase lima kantong jenazah. Unsur pusat (UP) dari FNA lima kantong jenazah adalah unsur jenazah yang merupakan kata nominal didahului oleh unsur lima kantong sebagai atribut yang merupakan frase bilangan. Frase bilangan lima kantong terdiri dari unsur lima yang berkategori kelas kata bilangan dan unsur kantong sebagai penyukat. Berikut disajikan diagram pohonnya.

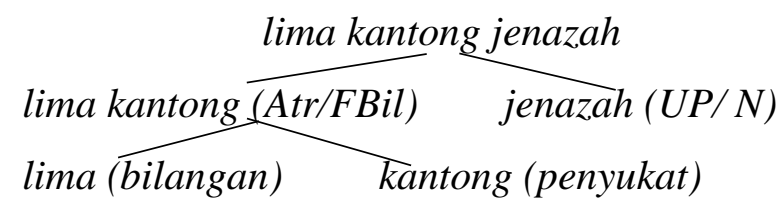

Pada kalimat (12) terdapat dua frase nominal atributif (FNA) yaitu frase produksi padi tahun 2018 dan 30 juta ton beras. FNA yang memiliki pola Bil + N adalah frase 30 juta ton beras. Unsur pusat (UP) dari FNA 30 juta ton beras adalah unsur beras yang merupakan kata nominal didahului oleh unsur 30 juta ton sebagai atribut yang merupakan frase bilangan. Frase bilangan 30 juta ton terdiri dari unsur 30 juta yang berkategori kelas kata bilangan dan unsur ton sebagai penyukat. Berikut disajikan diagram pohonnya.

$$
30 \text { uta } \frac{30 \text { juta ton juta ton beras }}{\text { (bilangan) }}\left(\text { Atrasil) }_{\text {ton (penyukat) }}(U P / N)\right.
$$

g. Pola Pola Nominal didahului Sandang $(\mathbf{S d}+\mathbf{N})$

Frase nominal atributif yang berpola $\mathrm{Sd}+\mathrm{N}$ dalam rubrik "opini" harian Rakyat Pos mempunyai frekuensi kemunculan sebanyak 39 dari 594 data yang ditemukan pada kalimat-kalimat dalam rubrik “opini” harian Rakyat Pos. Pola Sd + $\mathrm{N}$ ini merupakan pola frase nominal yang terdiri dari kata atau frase nominal sebagai unsur pusat (UP) didahului kata sandang sebagai atribut (Atr). Contoh:

(13) Salah satu yang menjadi perhatian adalah donatur atau sponsor yang ikut membiayai sang calon. (O2/127/12/7Jan21)

(14) Apalagi arsip tersebut menyangkut masa depan si warga masyarakat. (O1/501/02/25Jan21) 
Lingua Rima: Jurnal Pendidikan Bahasa dan Sastra Indonesia

Vol. 10 No. 3 September 2021

http://jurnal.umt.ac.id/index.php/lgrm

Pada kalimat (13) frase sang calon merupakan frase nominal atributif (FNA) yang memiliki pola $\mathrm{Sd}+\mathrm{N}$. Unsur pusat (UP) dari FNA sang calon adalah unsur calon yang merupakan kata nominal didahului oleh unsur sang sebagai atribut yang merupakan kata sandang. Berikut disajikan diagram pohonnya.

$$
\text { sang }(\widehat{\text { Str/sd }) \quad \text { calon }}(U P / N)
$$

Pada kalimat (14) terdapat dua frase nominal atributif (FNA) yakni frase arsip tersebut dan frase si warga masyarakat. Frase yang merupakan frase nominal atributif (FNA) adalah frase si warga masyarakat yang memiliki pola $\mathrm{Sd}+\mathrm{N}$. Unsur pusat (UP) dari FNA si warga masyarakat adalah unsur warga masyarakat yang merupakan frase nominal didahului oleh unsur si sebagai atribut yang merupakan kata sandang. Berikut disajikan diagram pohonnya.

$$
\begin{aligned}
& \text { Si warga masyarakat } \\
& \text { warga masyarakat }(U P / F N) \\
& \operatorname{warga}(U P / N) \quad \text { masyarakat }(U P / N)
\end{aligned}
$$

\section{Hubungan Makna Antarunsur Frase Nominal Atributif dalam Rubrik "Opini" Harian Rakyat Pos bulan Januari 2021}

Berdasarkan penelitian yang telah dilakukan pada frase nominal atributif dalam rubrik "opini" harian Rakyat Pos, maka diperoleh hubungan makna antarunsur frase nominal atributif sebanyak 5 hubungan makna. Adapun 5 hubungan makna tersebut akan dijelaskan sebagai berikut.

\section{a. Hubungan Makna 'Penerang'}

Frase nominal atributif yang memiliki hubungan makna penerang dalam rubrik “opini” harian Rakyat Pos memiliki frekuensi kemunculan sebanyak 113 dari 594 data yang dianalisis. Pada hubungan makna penerang, unsur atribut (Atr) merupakan penerang bagi unsur pusat (UP). Selain itu, hubungan makna penerang secara jelas ditandai dengan kemungkinan diletakkannya kata yang diantara unsurnya. Contohnya:

(15) Seandainya kedelai dijadikan tanaman utama disamping padi dan jagung, maka bisa dipastikan akan dapat memenuhi kebutuhan kedelai masyarakat Indonesia. (O2/593/12/29Jan21) 
Lingua Rima: Jurnal Pendidikan Bahasa dan Sastra Indonesia

Vol. 10 No. 3 September 2021

http://jurnal.umt.ac.id/index.php/lgrm

(16) Kita sedang menghadapi masalah besar, yang karena kehadirannya kita harus bergandengan tangan, bahu membahu untuk meringankan beban antara satu dengan yang lain. (O1/393/04/20Jan21)

Pada kalimat (15) terdapat frase nominal atributif yang memiliki hubungan makna penerang adalah FNA tanaman utama. FNA tanaman utama terdiri dari UP tanaman dan atribut utama yang memiliki hubungan makna penerang. Unsur utama sebagai atribut menerangkan unsur tanaman. Sesuai dengan ciri dari hubungan makna penerang, frase tanaman utama dapat disisipi kata yang diantara unsurnya. Jika diparafrasekan, frase tanaman utama akan menjadi frase tanaman yang utama.

Pada kalimat (16) terdapat frase nominal atributif yaitu frase masalah besar. FNA masalah besar terdiri dari UP masalah dan atribut besar yang memiliki hubungan makna penerang. Unsur besar sebagai atribut menerangkan unsur masalah. Sesuai dengan ciri dari hubungan makna penerang, frase masalah besar dapat disisipi kata yang diantara unsurnya. Jika diparafrasekan, frase masalah besar akan menjadi frase masalah yang besar.

\section{b. Hubungan Makna 'Pembatas'}

Frase nominal atributif yang memiliki hubungan makna pembatas dalam rubrik “opini” harian Rakyat Pos memiliki frekuensi kemunculan sebanyak 263 dari 594 data yang dianalisis. Berbagai hubungan makna seperti makna pemilik, makna tujuan, makna asal, dan makna bahan sesuai dengan teori Ramlan (2005) dirangkum menjadi satu hubungan makna pembatas. Pada hubungan makna pembatas, unsur atribut (Atr) merupakan pembatas bagi unsur pusat (UP). Selain itu, hubungan makna pembatas ditandai dengan ketidakmungkinan diletakkan kata yang, dan, atau, dan adalah diantara unsurnya. Contohnya:

(17) Pangkalpinang secara geografis diuntungkan sebagai ibukota Bangka Belitung. Sarana dan prasarana seperti perhotelan, transportasi, maupun tempat kuliner mudah dijumpai dan kualitas yang baik. (O1/030/03/5Jan21)

(18) Selanjutnya untuk sains, skor rata-rata siswa Indonesia mencapai 389 dengan skor rata-rata OECD yakni 489. (O2/041/01/5Jan21)

Pada kalimat (17) terdapat frase nominal atributif yaitu frase tempat kuliner. FNA tempat kuliner terdiri dari UP tempat dan atribut kuliner yang memiliki hubungan makna tujuan. Hubungan makna tujuan termasuk dalam hubungan makna pembatas. 


\section{Lingua Rima: Jurnal Pendidikan Bahasa dan Sastra Indonesia \\ Vol. 10 No. 3 September 2021 \\ http://jurnal.umt.ac.id/index.php/lgrm}

Unsur kuliner sebagai atribut membatasi unsur tempat sebagai tujuannya. Sesuai dengan ciri dari hubungan makna pembatas, frase tempat kuliner tidak dapat disisipi kata yang, dan, atau, dan adalah diantara unsurnya. Dikarenakan frase tempat kuliner memiliki makna tujuan, maka dapat diparafrasekan menjadi frase tempat untuk kuliner.

Pada kalimat (18) terdapat frase nominal atributif yaitu frase siswa Indonesia. FNA siswa Indonesia terdiri dari UP siswa dan atribut Indonesia yang memiliki hubungan makna asal. Hubungan makna asal termasuk dalam hubungan makna pembatas. Unsur Indonesia sebagai atribut menunjukkan asal dari unsur siswa. Sesuai dengan ciri dari hubungan makna pembatas, frase siswa Indonesia tidak dapat disisipi kata yang, dan, atau, dan adalah diantara unsurnya. Dikarenakan frase siswa Indonesia memiliki makna asal, maka dapat diparafrasekan menjadi frase siswa dari Indonesia.

\section{c. Hubungan Makna 'Penentu/ Penunjuk'}

Frase nominal atributif yang memiliki hubungan makna penentu atau penunjuk dalam kalimat-kalimat pada rubrik "opini" harian Rakyat Pos memiliki frekuensi kemunculan sebanyak 84 dari 594 data yang dianalisis. Hubungan makna penentu atau penunjuk ditandai dengan adanya kata nominal yang berupa kata ganti penunjuk di belakang unsur pusatnya. Contohnya:

(19) Dengan adanya pandemi ini, seharusnya sebagai masyarakat yang patuh aturan hendaknya kita menerapkan setiap instruksi yang telah dianjurkan oleh pemerintah. (O2/307/04/13Jan21)

(20) Namun orang tuanya justru mendukung siswa ini untuk melanjutkan studinya di bidang IPA. (O2/169/03/8Jan21)

Pada kalimat (19) terdapat frase nominal atributif yaitu frase pandemi ini. FNA pandemi ini terdiri dari UP pandemi dan atribut ini. Frase pandemi ini sudah tidak mungkin ditambah dengan atribut lagi. Walaupun dapat ditambah kata yang tetap bukan menyatakan hubungan penerang tetapi unsur ini pada frase pandemi ini menyatakan hubungan makna penentu atau penunjuk.

Pada kalimat (20) terdapat frase nominal atributif yaitu frase siswa ini. FNA siswa ini terdiri dari UP siswa dan atribut ini. Frase siswa ini sudah tidak mungkin ditambah dengan Atr lagi. Walaupun dapat ditambah kata yang tetap bukan menyatakan hubungan penerang tetapi unsur ini pada frase siswa ini menyatakan hubungan makna penentu atau penunjuk. 
Lingua Rima: Jurnal Pendidikan Bahasa dan Sastra Indonesia

Vol. 10 No. 3 September 2021

http://jurnal.umt.ac.id/index.php/lgrm

\section{d. Hubungan Makna 'Jumlah'}

Frase nominal atributif yang memiliki hubungan makna penentu atau penunjuk dalam kalimat-kalimat pada rubrik "opini” harian Rakyat Pos memiliki frekuensi kemunculan sebanyak 110 dari 594 data yang dianalisis. Contohnya:

(21) Ketiga produsen vaksin China itu juga menggelar uji efikasi di Indonesia, Pakistan, Arab Saudi, Meksiko dan Chile. (O2/422/19/20Jan21)

(22) Sinovac telah memvaksinasi lebih dari 90 persen karyawannya yang acap bepergian ke luar negeri. (O2/424/20/20Jan21)

Pada kalimat (21) terdapat frase nominal atributif yaitu frase ketiga produsen vaksin China. FNA ketiga produsen vaksin China terdiri dari UP produsen vaksin China dan atribut ketiga. Frase ketiga sebagai atribut yang menyatakan makna jumlah dari UP produsen vaksin China. Oleh karena itu, FNA ketiga produsen vaksin China mempunyai hubungan makna jumlah.

Pada kalimat (22) terdapat frase nominal atributif yaitu frase 90 persen karyawannya. FNA 90 persen karyawannya terdiri dari UP karyawannya dan atribut 90 persen. Frase 90 persen sebagai atribut yang menyatakan makna jumlah dari UP karyawannya yang telah divaksinasi. Oleh karena itu, FNA 90 persen karyawannya mempunyai hubungan makna jumlah.

\section{e. Hubungan Makna 'Sebutan'}

Frase nominal atributif yang memiliki hubungan makna sebutan dalam kalimatkalimat pada rubrik "opini” harian Rakyat Pos memiliki frekuensi kemunculan sebanyak 24 dari 594 data yang dianalisis. Berbagai hubungan makna seperti makna nama panggilan, nama gelar kesarjanaan, nama gelar jabatan, nama gelar keagamaan, dan nama gelar kepangkatan. Makna-makna tersebut dirangkum menjadi satu hubungan makna yakni hubungan makna sebutan. Contohnya:

(23) Adapun permasalahan selanjut nya, yang menjadi bawaan dari pola asuh dan cara orang tua menunjukkan kasih sayangnya pada sang anak. (O2/179/05/8Jan21)

Namun di sisi lainnya juga berkaitan dengan pola hubungan sosial (silaturahmi) yang secara tidak langsung terbentuk pada saat di undang dalam acara perayaan si tuan rumah. (O1/298/05/13Jan21)

Pada kalimat (49) terdapat frase nominal atributif yaitu sang anak. FNA sang anak terdiri dari UP anak dan atribut sang. Unsur sang sebagai atribut menyatakan 


\section{Lingua Rima: Jurnal Pendidikan Bahasa dan Sastra Indonesia \\ Vol. 10 No. 3 September 2021 \\ http://jurnal.umt.ac.id/index.php/lgrm}

makna nama panggilan. Makna nama panggilan termasuk dalam hubungan makna sebutan.

Pada kalimat (50) terdapat frase nominal atributif yaitu si tuan rumah. FNA si tuan rumah terdiri dari UP tuan rumah dan atribut si. Unsur si sebagai atribut menyatakan makna nama panggilan. Makna nama panggilan termasuk dalam hubungan makna sebutan.

\section{SIMPULAN}

Berdasarkan pembahasan di atas, maka diperoleh beberapa kesimpulan yaitu pola frase nominal atributif (FNA) dalam rubrik "opini" harian Rakyat Pos yang ditemukan sebanyak tujuh pola frase nominal atributif. Pola-pola tersebut, yaitu $\mathrm{N}+\mathrm{N}$ sebanyak 305 data, $\mathrm{N}+\mathrm{V}$ sebanyak 118 data, $\mathrm{N}+$ Bil sebanyak 12 data, $\mathrm{N}+$ Ket sebanyak 7 data, $\mathrm{N}+$ FD sebanyak 32 data, Bil + N 81 data, dan Sd + N sebanyak 39 data. Pola FNA yang paling banyak ditemukan adalah pola $\mathrm{N}+\mathrm{N}$ dengan frekuensi kemunculan 305 dari 594 data. Sedangkan pola yang paling jarang muncul adalah pola $\mathrm{N}+$ Ket dengan frekuensi kemunculan 7 dari 594 data. Hubungan makna antarunsur frase nominal atributif (FNA) yang ditemukan dalam rubrik “opini” harian Rakyat Pos sebanyak lima hubungan makna. Hubungan makna antarunsur frase nominal atributif yang ditemukan adalah hubungan makna penerang sebanyak 113 data, pembatas sebanyak 263 data, penentu atau penunjuk sebanyak 84 data, jumlah sebanyak 110 data, dan sebutan sebanyak 24 data. Hubungan makna yang paling sering ditemukan adalah hubungan makna pembatas dengan frekuensi kemunculan sebanyak 263 dari 594 data. Sedangkan hubungan makna yang paling jarang ditemukan adalah hubungan makna sebutan dengan frekuensi kemunculan sebanyak 24 dari 594 data. Saran bagi peneliti lain yaitu penelitian ini diharapkan dapat memberikan kontribusi pengetahuan mengenai nominal atributif.

\section{E. DAFTAR PUSTAKA}

Chaer, A. (2015). Sintaksis Bahasa Indonesia: Pendekatan Proses. Jakarta: Rineka Cipta.

Harian Rakyat Pos edisi Januari 2013

Ismail, M. M. (2016). Penggunaan Frasa Nominal Pada Rubrik Cerpen Koran Kompas Bulan Juni-Agustus 2014. In SKRIPSI. Yogyakarta: Universitas Negeri Yogyakarta.

Kinanti, K. P (2020). Frasa Nomina Atributif dalam Bahasa Jawa Dialek Jawa Timur. Jurnal Linguista. Vol 4 No 2 